\title{
Research Paper: Protective Effect of the Viola spathulata Extract on NCX3 Gene Expression in an Animal Model of Cerebral Ischemia
}

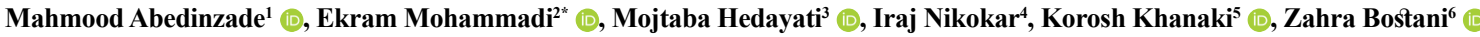 \\ 1. Medical Biotechnology Research Center, Department of Physiology, School of Paramedicine, Guilan University of Medical Sciences, Rasht, Iran \\ 2. Department of Medical Physiology, School of Medicine, Iran University of Medical Sciences, Tehran, Iran. \\ 3. Department of Microbiology, Faculty of Medicine, Guilan University of Medical Sciences, Rasht, Iran. \\ 4. Medical Biotechnology Research Center, Department of Laboratory of Microbiology, School of Nursing, Midwifery, and Paramedicine, Guilan University \\ of Medical Sciences, Rasht, Iran. \\ 5. Medical Biotechnology Research Center, Department of Clinical Biochemistry, School of Paramedicine, Guilan University of Medical Sciences, Rasht, Iran. \\ 6. Social Determinants of Health Research Center, School of Nursing and Midwifery, Guilan University of Medical Sciences, Rasht, Iran.
}

\begin{tabular}{|c|c|}
\hline $\begin{array}{l}\text { Use vourd device toscsan } \\
\text { and read the article online }\end{array}$ & Citation Abedinzade, M., Mohammadi, E., Hedayati, M., Nikokar, I., Khanaki, K., Bostani, Z. Protective Effect of the Viola \\
\hline 口iris & $\begin{array}{l}\text { spathulata Extract on } N C X 3 \text { Gene Expression in an Animal Model of Cerebral Ischemia. Basic and Clinical Neuroscience, } \\
\text { 13(1), 71-80. http://dx.doi.org/10.32598/bcn.2021.2030.1 }\end{array}$ \\
\hline 罟日e地 & doi http://dx.doi.org/10.32598/ben.2021.2030.1 \\
\hline
\end{tabular}

\section{(c) (1) (5)}

Article info:

Received: 09 Sep 2019

First Revision: 05 Mar 2020

Accepted: 16 Aug 2020

Available Online: 01 Jan 2022

Keywords:

Viola spathulata, Viola extract, Brain ischemia, NCX3 gene, Stroke, Neuroprotective

\section{AB S T RAC T}

Introduction: Viola plant has been used traditionally to treat neurological disorders. We aimed at determining whether pretreatment with Viola spathulata extract can alleviate the severity of ischemic-reperfusion damages and exert its protective effects through the regulation of a sodium/calcium exchanger $(N C X 3)$ gene expression in a rat brain.

Methods: Male Wistar rats were divided into two main groups: one main group for evaluating Neurologic Deficit Score (NDS) and Infarct Volume (IV) and the other group for the evaluation of $N C X 3$ gene expression in the brain tissue. The latter group was subdivided into the intact, control (vehicle), sham, V5, and V10. The vehicle (control) subgroup received Dimethyl Sulfoxide (DMSO), and V5 and V10 subgroups received V. spathulata extract at the doses of 5 and $10 \mathrm{mg} / \mathrm{kg}$ (IP), respectively, for 7 days. After pretreatment, we carried out Middle Cerebral Artery Occlusion (MCAO) for $60 \mathrm{~min}$.

Results: In the V5 and V10 subgroups, NDS and IV significantly decreased. MCAO upregulated $N C X 3$ gene expression in the core, penumbra, and subcortical regions compared with the intact subgroup. The V5 subgroup significantly downregulated the $N C X 3$ gene expression level in the core compared with the control subgroup. The V10 subgroup showed downregulation of the $N C X 3$ gene expression level in the core, penumbra, and subcortex compared with the control subgroup.

Conclusion: V. spathulata extract may have a neuroprotective role against MCAO-induced ischemic brain damage, possibly by preventing the alteration of $N C X 3$ gene expression level.

\footnotetext{
* Corresponding Author:

Ekram Mohammadi, PhD Candidate.

Address: Department of Medical Physiology, School of Medicine, Iran University of Medical Sciences, Tehran, Iran. Tel: +98 (21) 88622532

E-mail: ekram.mohammadi@yahoo.com
} 


\section{Highlights}

- MCAO results Infarct Volume (IV) and Neurologic Deficit Score (NDS);

- MCAO upregulated NCX3 gene expression in brain tissues;

- Viola spathulata extract pretreatment decreased IV and NDS in brain ischemia;

- Viola spathulata pretreatment downregulated NCX3 gene expression in brain tissues.

\section{Plain Language Summary}

Stroke is the second leading cause of death and long term disability. Recently it has been reported that herbal extracts have protective role in ischemia injury. In Iranian traditional medicine Viola plant has a long history to treat disorders such as cancer. So we designed an animal study to investigate Viola plant extract in brain ischemia injury. Viola spathulata extract was administrated to rats for seven days, then animal model of brain ischemia was operated on them and some behavioral, histological and molecular factors were analyzed. Our findings showed that Viola spathulata extract improved behavioral disability, decreased infarct volume in brain tissue, and modulate Sodium/Calcium exchanger 3 gene expression. It could be concluded that Viola spathulata has the neuroprotective effect in animal stroke model and is a good candidate for nutritional supplements, although further studies are needed.

\section{Introduction}

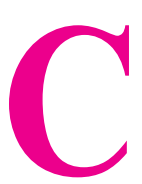

erebrovascular attack or stroke is a sudden disruption of blood supply to the brain which triggers serious consequences such as cerebral infarction and neurological deficits. In developing countries such as Iran, stroke is the second leading cause of death and long-term disability (Bacigaluppi, Pluchino, Martino, Kilic, \& Hermann, 2008). Ischemia is a major type of stroke (Mergenthaler, Dirnagl, \& Meisel, 2004). Several changes are initiated by ischemia and reperfusion, such as inhibition of electron transport, decreasing ATP and $\mathrm{pH}$, increasing cell $\mathrm{Ca}^{2+}$, releasing glutamate, and increasing arachidonic acid. Also, gene activation leads to the synthesis of the cytokines and enzymes involved in free radical production (Lipton, 1999).

$\mathrm{Na}^{+} / \mathrm{Ca}^{2+}$ exchanger (NCX) has nine transmembrane segments widely distributed in the brain (Blaustein \& Lederer, 1999). This protein couples transmembrane movement of $\mathrm{Ca}^{2+}$ to reciprocal movements of $\mathrm{Na}^{+}$in a bidirectional way in the Central Nervous System (CNS) (Meyer, 1989). In the CNS, NCX plays a fundamental role in controlling changes in the intracellular concentrations of $\mathrm{Na}^{+}$and $\mathrm{Ca}^{2+}$ ions under physiologic conditions (Canitano et al., 2002). NCX1, NCX2, and NCX3 are three different genes of the $N C X$ family that are differentially expressed in distinct regions of the CNS (Papa et al., 2003). Depending on the intracellular $\mathrm{Ca}^{2+}$ and $\mathrm{Na}^{+}$ concentrations $\left(\left[\mathrm{Ca}^{2+}\right] \mathrm{i}\right.$ and $\left.\left[\mathrm{Na}^{+}\right] \mathrm{i}\right), \mathrm{NCX}$ can act either in the forward mode, coupling the uphill extrusion of $\mathrm{Ca}^{2+}$ to the influx of $\mathrm{Na}^{+}$ions, or in the reverse mode, mediating the extrusion of $\mathrm{Na}^{+}$and the influx of the $\mathrm{Ca}^{2+}$ ions (Blaustein \& Lederer, 1999). NCX activation reduces the brain infarct volume extension after permanent Middle Cerebral Artery Occlusion (MCAO). Also, the selective pharmacological blockade of NCX worsens the brain lesion, suggesting a protective role played by the exchanger during the events leading to brain ischemia (Pignataro et al., 2004). NCX3, unlike the other NCXs family members (NCX1 and NCX2), has a peculiar capability to maintain $\left[\mathrm{Ca}^{2+}\right]$ i homeostasis even when ATP levels are reduced considerably. Therefore, it has a major role in neuronal preservation during hypoxic conditions (Mohammadi \& Bigdeli, 2014; Secondo et al., 2007).

Recently, it has been demonstrated that herbal extracts and oils such as olive oil (Mohagheghi, Bigdeli, Rasoulian, Zeinanloo, \& Khoshbaten, 2010), Coriandrum sativum (Linn) (Vekaria, Patel, Bhalodiya, Patel, V., Desai, \& Tirgar, 2012) and Ocimum basilicum (Bora, Arora, \& Shri, 2011) have a protective role in ischemia-reperfusion injury. It has also been shown that Viola odorata and Viola tricolor have antioxidant activities and protect neuronal cells against serum glucose deprivation (Mousavi, Naghizade, Pourgonabadi, \& Ghorbani, 2016).

Viola has a long remedial history in Iranian traditional medicine to treat disorders such as cancer (Koochek, 
Pipelzadeh, \& Mardani, 2003). Previous studies demonstrated that viola tissue contains melatonin (Ansari et al., 2010; Kim, Yoon, \& Park, 2011). Plants with a high level of melatonin have been used traditionally to treat neurological disorders (Murch, Simmons, \& Saxena, 1997) and diseases caused by free radicals generation (Chen, Huo, Tan, Liang, Zhang, \& Zhang, 2003). It has also been found that melatonin reduces hypoxia-ischemia damages, improves sleep, ameliorates cardiac ischemia/reperfusion injuries, and inhibits oxidative stress-mediated endothelial cell death (Lin et al., 2016; Manchester et al., 2015; Mao et al., 2016; Nduhirabandi, Lamont, Albertyn, Opie, \& Lecour, 2016). Treatment with melatonin improves calcium handling by preserving $S E R C A$ gene expression in hypoxic rats and performs as a cardioprotective factor against myocardial injury (Yeung, Hung, \& Fung, 2008).

Because of using viola in traditional medicine to treat neurodegenerative diseases, we designed a study to evaluate whether the administration of Viola spathulata can alleviate brain injuries by using an in vivo model of transient focal cerebral ischemia in rats. In the second part, because calcium overload is a major mechanism in ischemic injury (Dirnagl, Iadecola, \& Moskowitz, 1999), we sought to identify whether such effects on brain ischemia might be associated with changes in the expression of the $N C X 3$ gene.

\section{Methods}

Experimental procedures

\section{Viola extraction}

Aerial parts of $V$. spathulata were collected from Gadouk neck, Firoozkouh road, Savadkouh City (Mazandaran Province, Iran) in May 2017, and the species were authenticated at the herbarium of the Department of Biology, School of Medical Sciences (Sari Payame Noor University; Herbarium No.: SPNH-4727).

The aerial parts of $V$. spathulata were separately dried, powdered, and extracted with $70 \%$ ethanol in a Soxhlet apparatus for $48 \mathrm{~h}$. The hydroalcoholic extracts were then concentrated in a water bath and kept at $-20^{\circ} \mathrm{C}$ until use.

Finally, the extract was dissolved in Dimethyl Sulfoxide (DMSO) to be used in this study.

\section{Animals and group assignment}

All experimental animal procedures were approved and conducted under the Animal Research and Ethics Committee (IR.GUMS.REC.1394.323) of Guilan Uni- versity of Medical Sciences. Every attempt was made to minimize the number of animal use and their suffering. The rats were housed under controlled temperature $\left(24^{\circ} \mathrm{C}\right)$ with food and water ad libitum with lights on from 07:00 to 19:00 (light cycle) and off from 19:00 to 07:00 (dark cycle).

Male Wistar rats (200-250 g) were divided into two main groups, and each group was divided into the control (vehicle), sham, intact, V5 (V. spathulata $5 \mathrm{mg} / \mathrm{kg} / \mathrm{d}$ ) (Liu et al., 2014; Robertson et al., 2012) and V10 ( $V$. spathulata $10 \mathrm{mg} / \mathrm{kg} / \mathrm{d}$ ) (Letechipía-Vallejo, GonzálezBurgos, \& Cervantes, 2001; Robertson et al., 2012) subgroups. One main group was used for evaluating Neurologic Deficit Score (NDS) and Infarct Volume (IV), Viola extracts ( 5 and $10 \mathrm{mg} / \mathrm{kg}$ ) was administrated by i.p. injection for 7 days before MCAO operation and control group received DMSO. (Yanpallewar, Rai, Kumar, \& Acharya, 2004). After pretreatment, a 60-min MCAO was carried out in the control, V5, and V10 subgroups. In the sham subgroup, all steps were similar to the control group, except MCAO. Data from the sham and intact subgroups were pooled together, as there was no significant difference between them.

\section{Focal cerebral ischemia}

The rats were weighed and anesthetized with chloral hydrate (400 mg/kg bodyweight; Merck, Germany). MCAO was applied as described previously by Longa et al. (Longa, Weinstein, Carlson, \& Cummins, 1989). Briefly, under microscopic surgery, a 3-0 silicone-coated nylon filament was introduced through the external carotid artery stump. The occluder was advanced into the internal carotid artery 20 to $22 \mathrm{~mm}$ past the carotid bifurcation until mild resistance indicated that the tip was lodged in the anterior cerebral artery and blocked the blood flow to the middle cerebral artery. After $60 \mathrm{~min}$ of ischemia, reperfusion was started by withdrawing the filament. During the surgery, the animal's body temperature was monitored and maintained at around $37^{\circ} \mathrm{C}$ by using a heating and cooling surface.

\section{Neurologic Deficit Score (NDS)}

After the filament was withdrawn, the rats were returned to their separate cages. The rats were assessed neurologically $24 \mathrm{~h}$ later by an observer blinded to the animal groups. The neurobehavioral scoring was performed using the 6-point scale previously described by Longa et al. (Longa et al., 1989) as follows: normal motor function $=0$; flexion of contralateral forelimb on suspension vertically by the tail, failure to extend forepaw 
$=1$; circling to the contralateral side but normal posture at rest $=2$; loss of righting reflex $=3$; and no spontaneous motor activity $=4$. Death was considered for scoring 5 only when a large infarct volume was present without subarachnoid hemorrhage. The rats were excluded from the study when they died due to subarachnoid hemorrhage or pulmonary insufficiency and asphyxia.

\section{Infarct Volume (IV) assessment}

After killing animals with chloral hydrate $(800 \mathrm{mg} / \mathrm{kg})$, they were decapitated, and their brains were rapidly removed and cooled in saline $\left(4^{\circ} \mathrm{C}\right)$ for $15 \mathrm{~min}$. Eight 2-mm thick coronal sections were cut (Brain Matrix, Tehran, Iran) through the brain, starting at the olfactory bulb. The slides were immersed in 2\% 2, 3, 5-triphenyl tetrazolium chloride solution (Merck, Germany) and kept at $37^{\circ} \mathrm{C}$ in a water bath for $15 \mathrm{~min}$. The slices were then digitally photographed by a camera (iPhone $5 \mathrm{~s}$ ) connected to a computer. Unstained areas were defined as infarct and measured using the image analysis software (Image Tools, National Institutes of Health). The infarct volume was calculated by measuring the unstained and stained area in each hemisphere slice in three defined regions (core, penumbra, and subcortex), multiplying by slice thickness $(2 \mathrm{~mm})$, followed by summiting all eight slices according to the method by Swanson et al. (Swanson et al., 1990): corrected infarct volume=left hemisphere volume - (right hemisphere volume - infarct volume).

\section{Brain sampling}

The intact (I) (no surgery), control, sham-operated, V5+MCAO, and V10+ MCAO animals were killed by chloral hydrate $(800 \mathrm{mg} / \mathrm{kg}) 24 \mathrm{~h}$ after MCAO operation and decapitated for measurement of $N C X 3$ gene expression. Core, penumbra, and subcortex of the brain tissues were isolated as previously described by Lei et al. (Lei, Popp, Capuano-Waters, Cottrell, \& Kass, 2004) (Figure 1).

NCX3 gene measurement

\section{RNA extraction}

After excision of the brain tissues, tissue sections (10 $\mathrm{mg}$ ) were prepared, turned into small pieces using a grinder, and were transferred to the $1 \mathrm{~mL}$ YTzol Pure RNA solution (YEKTA TAJHIZ AZMA, Iran). RNA was extracted according to the manufacturer's instructions. Briefly homogenized samples were incubated for $5 \mathrm{~min}$ at $15^{\circ} \mathrm{C}$ to $30^{\circ} \mathrm{C}$. Then, $200 \mu \mathrm{L}$ of chloroform was added to the sample tube and vigorously shook for $15 \mathrm{~s}$. The sample tube was incubated at room temperature for
2-3 min. The specimens were centrifuged at $12000 \times \mathrm{g}$ for $10 \mathrm{~min}$ at $4^{\circ} \mathrm{C}$ (Sigma 3-18KS, Germany). The transparent supernatant was transferred to a $1.5 \mathrm{~mL}$ nucleasefree Eppendorf tube, and $500 \mu \mathrm{L}$ isopropanol was added. The tubes were mixed well by inverting several times. The samples were incubated at $15^{\circ} \mathrm{C}-30^{\circ} \mathrm{C}$ for $10 \mathrm{~min}$ and centrifuged at $12000 \times \mathrm{g}$ for $10 \mathrm{~min}$ at $4^{\circ} \mathrm{C}$. Then, RNA washing was done using $1 \mathrm{~mL}$ of $75 \%$ ethanol (in nuclease-free water) (CinnaGen, Iran). The precipitant was dissolved in $20 \mu \mathrm{L}$ of nuclease-free water, and the purity of the extracted RNA was determined through the A260/A280 ratio using the NanoDrop system (Thermo Fisher Scientific Inc., USA).

\section{DNase I treatment}

DNase I is an endonuclease that digests single- and double-stranded DNA. To prepare DNA-free RNA before real-time Polymerase Chain Reaction (PCR), we treated the extracted RNA with DNase I, an RNase-free enzyme, according to the manufacturer's protocol (Thermo Fisher Scientific Inc., USA). Briefly, $1 \mu \mathrm{g} / \mu \mathrm{L}$ RNA, $1 \mu \mathrm{L} 10 \mathrm{X}$ reaction buffer with $\mathrm{MgCl}_{2}$, and $1 \mu \mathrm{L}$ DNase I, RNase-free, were added into a $1.5 \mathrm{~mL}$ nuclease-free microtube and then reached $10 \mu \mathrm{L}$ using nuclease-free water and mixed mildly. The contents were transferred to a $37^{\circ} \mathrm{C}$ water bath for $30 \mathrm{~min}$, and $1 \mu \mathrm{L}$ of EDTA (50 $\mathrm{mM}$ ) was added and incubated at $65^{\circ} \mathrm{C}$ for $10 \mathrm{~min}$.

\section{Complementary DNA synthesis}

cDNA was synthesized from $1 \mu \mathrm{g} / \mu \mathrm{L}$ total RNA with reverse transcriptase (HyperScript ${ }^{\mathrm{TM}}$ First-strand Synthesis Kit, Gene All, South Korea). Briefly, $1 \mu \mathrm{g} / \mu \mathrm{L}$ RNA, 1 $\mu \mathrm{L}$ oligo(dT) primer $(50 \mu \mathrm{M})$, and $1 \mu \mathrm{L}$ dNTPs $(10 \mathrm{mM})$ were added into a $0.2 \mathrm{~mL}$ nuclease-free microtube and then reached $14 \mu \mathrm{L}$ by nuclease-free water and mildly mixed. The contents were transferred to a $65^{\circ} \mathrm{C}$ water bath for $5 \mathrm{~min}$ and immediately placed on ice for at least $1 \mathrm{~min}$. Following a small spinning, the mixture was pipetted into the reaction tube containing $2 \mu \mathrm{L}$ of RTase reaction buffer $(10 \mathrm{x}), 2 \mu \mathrm{L}$ of $0.1 \mathrm{M}$ DTT, $1 \mu \mathrm{L}$ of HyperScript $^{\mathrm{TM}}$ reverse transcriptase $(200 \mathrm{U} / \mu \mathrm{L})$, and $1 \mu \mathrm{L}$ of ZymAll ${ }^{\mathrm{TM}} \mathrm{RNase}$ inhibitor. After brief centrifugation, the microtubes were incubated at $55^{\circ} \mathrm{C}$ for $60 \mathrm{~min}$. The termination of the reaction was done by incubating at $85^{\circ} \mathrm{C}$ for $5 \mathrm{~min}$. Finally, the samples were placed on ice for a while and then preserved in a $-20^{\circ} \mathrm{C}$ freezer until needed.

\section{Real-Time PCR}

Following the extraction of total RNA from the treated and untreated groups and the synthesis of cDNA, the 
Table 1. The sequences of the gene-specific Polymerase Chain Reaction (PCR) primers for real-time PCR

\begin{tabular}{cccc}
\hline Gene & NCBI Code & Forward & Reverse \\
\hline $62 \mu g$ & NM_012512.2 & TACATGTCTCGGTCCCAGGT & AATTCACACCCACCGAGACC \\
NCX3 & NM_078620.2 & CGACGGTACAAGAGCACACT & TTCCATGTGTCCGCTGGTAC \\
\hline
\end{tabular}

NEUR SCIENCE

$\beta 2 \mu \mathrm{g}: \beta 2$ microglobulin; NCX3: $\mathrm{Na}^{+} / \mathrm{Ca}^{2+}$ exchanger; NCBI: National Center for Biotechnology Information.

real-time PCR technique was exploited to determine the changes in the expression of $N C X 3$ (NCBI Reference Sequence: 017593995.1_). The expression of NCX3 mRNAs was quantified compared to the $\beta$-actin gene as a reference gene and represented relative gene expression. The PCR primers were designed by Primer3web (version 4.0.0), and the sequences and product sizes are given in Table 1 . The specificity of the designed primers was checked for each interest gene using the PrimerBLAST system available at the National Center for Biotechnology Information (NCBI).

We employed a reaction buffer, including $1 \mu \mathrm{L}$ of each primer, $10 \mu \mathrm{L}$ SYBR Green reagent (YEKTA TAJHIZ AZMA, Iran), $4 \mu \mathrm{L}$ diluted cDNA, and $4 \mu \mathrm{L}$ nucleasefree water using a real-time PCR method (Applied Biosystems, StepOne ${ }^{\mathrm{TM}}$, USA). The thermal program was initially planned at $95^{\circ} \mathrm{C}$ for $10 \mathrm{~min}$ and then continued with 40 tow-step cycles, at $95^{\circ} \mathrm{C}$ for $10 \mathrm{~s}$ and $60^{\circ} \mathrm{C}$ for $60 \mathrm{~s}$, and finally terminated with a cycle at $72^{\circ} \mathrm{C}$ for 5 minutes. Each amplification product was analyzed by a dissociation curve certifying that for each gene, the amplified product showed all nonspecific bands or primer dimer formation. The differences between mRNA expression of the reference and test samples were calculated, and the relative mRNA expressions of $N C X 3$ were calculated using the $\mathrm{Ct}$ method $\left(2^{-\Delta \mathrm{DDt}}\right)$ (Livak \& Schmittgen, 2001). All reactions were run in triplicate.

\section{Statistical analysis}

NCX gene expression and IV were compared using a 1-way Analysis of Variance (ANOVA). NDS was analyzed using the Mann-Whitney $U$ test. Data were expressed as Mean \pm SEM, and a P-value of less than 0.05 was considered significant. SPSS v. 16 software was used for data analysis.

\section{Results}

Effects of V. spathulata pretreatment on NDS and IV

Median NDS significantly reduced in the V5 and V10 groups compared with the control group $(\mathrm{P}=0.004$ and
$\mathrm{P}=0.02$, respectively) (Table 2 ). The putative beneficial effects of 7 days of pretreatment with $5 \mathrm{mg} / \mathrm{kg}$ of $V$. spathulata extract were confirmed by reducing the IV of the core, penumbra, and subcortex regions $(\mathrm{P}=$ $0.02, \mathrm{P}=0.0001$, and $\mathrm{P}=0.0001$, respectively; Figure 2). Seven days of pretreatment with $10 \mathrm{mg} / \mathrm{kg}$ of $\mathrm{V}$. spathulata extract also reduced IV in the core, penumbra, and subcortex regions significantly $(\mathrm{P}=0.01, \mathrm{P}=0.0001$, and $\mathrm{P}=0.0001$, respectively; Figure 3 ). There was no significant difference in NDS and IV between the rats treated with 5 and $10 \mathrm{mg} / \mathrm{kg}$ of $V$. spathulata extract.

\section{Effects of V. spathulata Pretreatment on NCX3} gene expression

Brain Ischemia (MCAO) upregulated $N C X 3$ gene expression in the core $(\mathrm{P}=0.0001)$, penumbra $(\mathrm{P}=0.007)$, and subcortex $(\mathrm{P}=0.38)$ regions significantly compared with the intact subgroup (Figure 4).

Pretreatment with $5 \mathrm{mg} / \mathrm{kg} \mathrm{V}$. spathulata down-regulated $N C X 3$ gene expression level in the core $(\mathrm{P}=0.001)$ region significantly compared with the control group (Figure 4).

Pretreatment with $10 \mathrm{mg} / \mathrm{kg} V$. spathulata down-regulated $N C X 3$ gene expression level in core $(\mathrm{P}=0.0001)$, penumbra $(\mathrm{P}=0.011)$, and subcortex $(\mathrm{P}=0.047)$ regions compared with the control group (Figure 4).

\section{Discussion}

NDS and IV are considered indicators of neurologic deficits in cerebral ischemia/reperfusion damage. Our results demonstrated that preconditioning with $V$. spathulata at the doses of 5 and $10 \mathrm{mg} / \mathrm{kg}$ reduced IV and NDS in three regions of the brain (core, penumbra, and subcortex). In the present study, administration of $V$. spathulata was done for the first time in the animal model of cerebral ischemia. Our results confirmed that $V$. spathulata had a protective role in ischemia-reperfusion injury. Similar previous studies have shown the protective role of olive oil (Mohagheghi et al., 2010), Coriandrum sativum (Linn.) (Vekaria et al., 2012), and Ocimum basilicum (Bora et al., 2011) in ischemia-reperfusion injury. Ischemic-reperfusion leads to the generation of 
Table 2. The distribution of neurologic deficit score in each experimental group

\begin{tabular}{|c|c|c|c|c|c|c|c|c|c|}
\hline \multirow{2}{*}{ Experimental Groups } & \multirow{2}{*}{ Median } & \multicolumn{6}{|c|}{ Neurologic Deficit Score } & \multirow{2}{*}{ Total (n) } & \multirow{2}{*}{ P-Value } \\
\hline & & 0 & 1 & 2 & 3 & 4 & 5 & & \\
\hline Control & 3 & 0 & 0 & 1 & 3 & 2 & 0 & 6 & - \\
\hline V5 & 1 & 1 & 4 & 3 & 1 & 0 & 0 & 6 & ${ }^{* *} \mathrm{P}<0.01$ \\
\hline V10 & 2 & 3 & 3 & 2 & 1 & 0 & 0 & 6 & $\begin{array}{l}{ }^{*} \mathrm{P}<0.05 \\
{ }^{\#} \mathrm{P}<0.05\end{array}$ \\
\hline
\end{tabular}

NEUR SCIENCE

${ }^{* *} \mathrm{P}<0.01$ significant differences between the V5 (Viola spathulata, $5 \mathrm{mg} / \mathrm{kg} / \mathrm{d}$ ) and control groups; $\mathrm{P}<0.05$ significant difference between the V10 (Viola spathulata, $10 \mathrm{mg} / \mathrm{kg} / \mathrm{d}$ ) and control groups; ${ }^{\#} \mathrm{P}<0.05$ significant difference between the V5 and V10 groups.

excessive Reactive oxygen Species (ROS) (Amantea et al., 2009), which causes oxidative damage to the cellular and mitochondrial structures. These changes ultimately result in the initiation of some pathways that lead to apoptotic and necrotic cell death (Manzanero, Santro, \& Arumugam, 2013). Viola tricolor and Viola odorata extracts protected the neuronal cell against adverse effects of intracellular ROS, which resulted in serum glucose deprivation (Mousavi et al., 2016). Therefore, V. spathulata might protect the neural cells from ischemia-reperfusion damage, probably alleviating ROS effects. However, in our study, intracellular ROS was not evaluated.

The $N C X 3$ is a bi-directional membrane ion transporter that exchanges $\mathrm{Ca}^{2+}$ and $\mathrm{Na}^{+}$ions across the cell membrane in the CNS and contributes significantly to maintaining intracellular $\mathrm{Ca}^{2+}$ homeostasis during experimental conditions mimicking ischemia (Secondo et al., 2007). It has been suggested that during ischemia, the calcium entry mode of NCX may account for a major portion of the calcium influx and induced excitotoxicity in cerebellar granule cells (Czyż \& Kiedrowski, 2002). However, to confirm the hypothesis that NCX acts as an exchanger contributing to calcium homeostasis during ischemia, it is necessary to measure calcium levels in the early hours after the stroke. $N C X 1$ mRNA was upregulated in the peri-infarct area with the induction of permanent MCAO in rats (Boscia et al., 2006). Bano et al. demonstrated that $N C X 3$ is cleaved and inactivated during ischemia in a rat model of focal ischemia (Bano et al., 2005). In our study, $N C X 3$ gene transcription was upregulated after $24 \mathrm{~h}$ reperfusion in the brain of MCAO rats; thus, a possible mechanism of $N C X 3$ gene up-regulation is a compensatory response to cleavage of $N C X 3$ isoform during one-hour ischemia.

This work is the first study to exhibit the effect of $V$. spathulata on NCX3 gene transcription in neurological

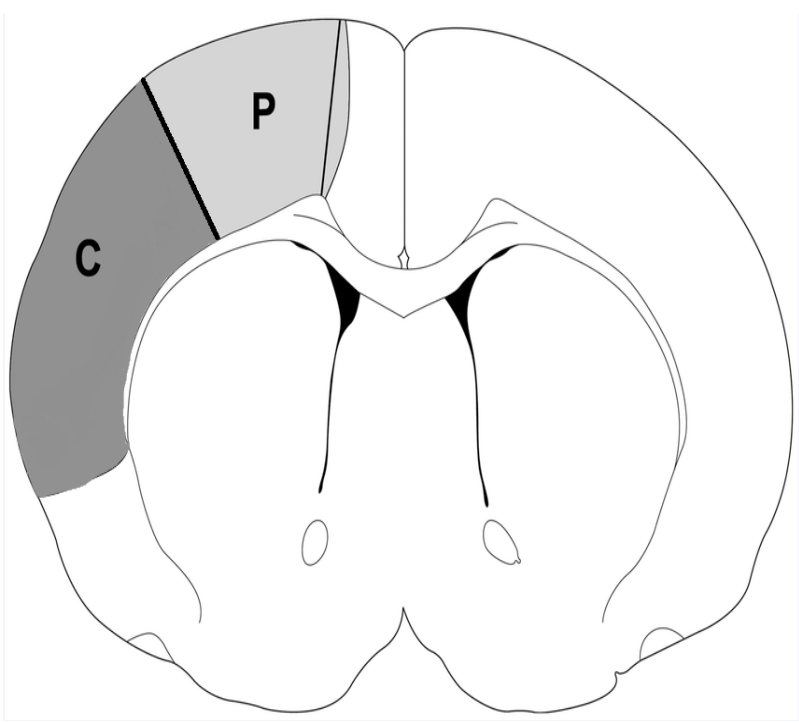

Figure 1. Schematic drawing showing the brain regions 5-mm from the frontal pole of the brain

Shaded areas indicate the ischemic areas. P: ischemic penumbra; C: ischemic core; S: subcortex. 


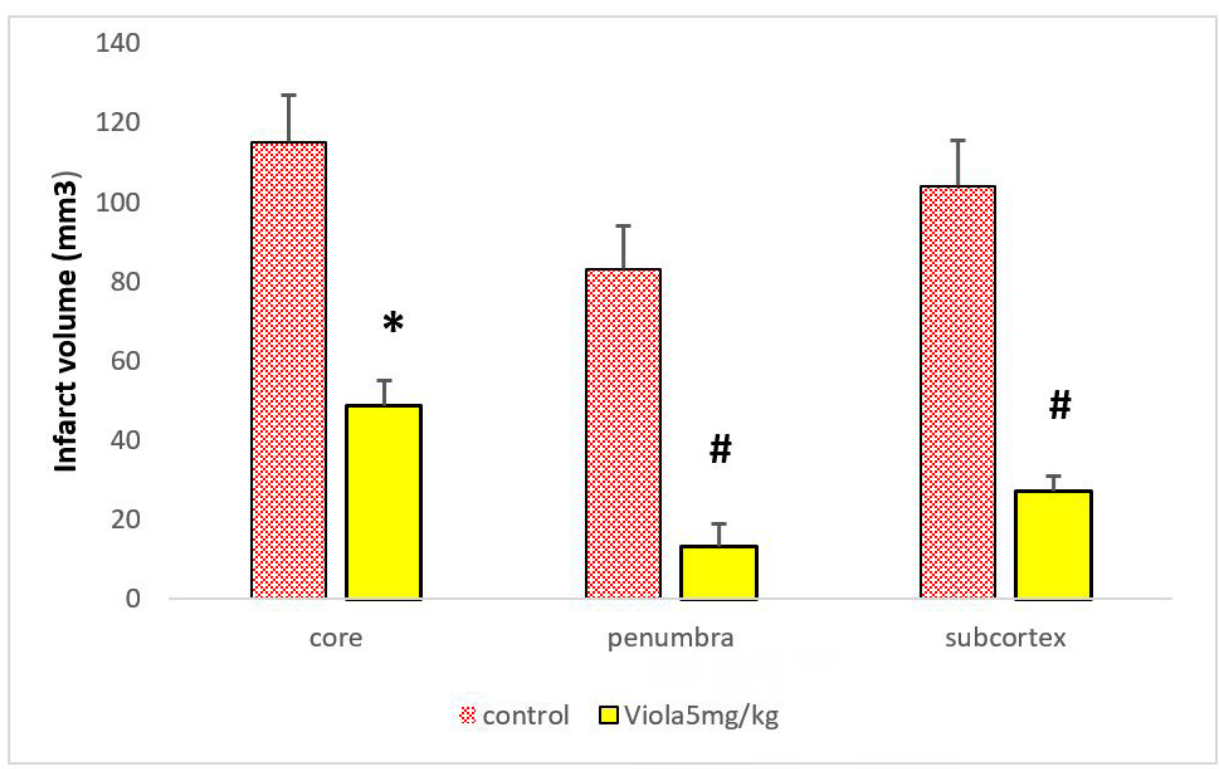

NEUR SCIENCE

Figure 2. The effect of Viola spathulata $(5 \mathrm{mg} / \mathrm{kg}$ ) pretreatment on infarct volume in the core, penumbra and subcortex areas compared with the control group $(\mathrm{n}=7)$.

Values are presented as Mean \pm SEM obtained from two independent experiments in the core, penumbra and subcortex of the brain.

${ }^{*} \mathrm{P}<0.05, \# \mathrm{P}<0.001$

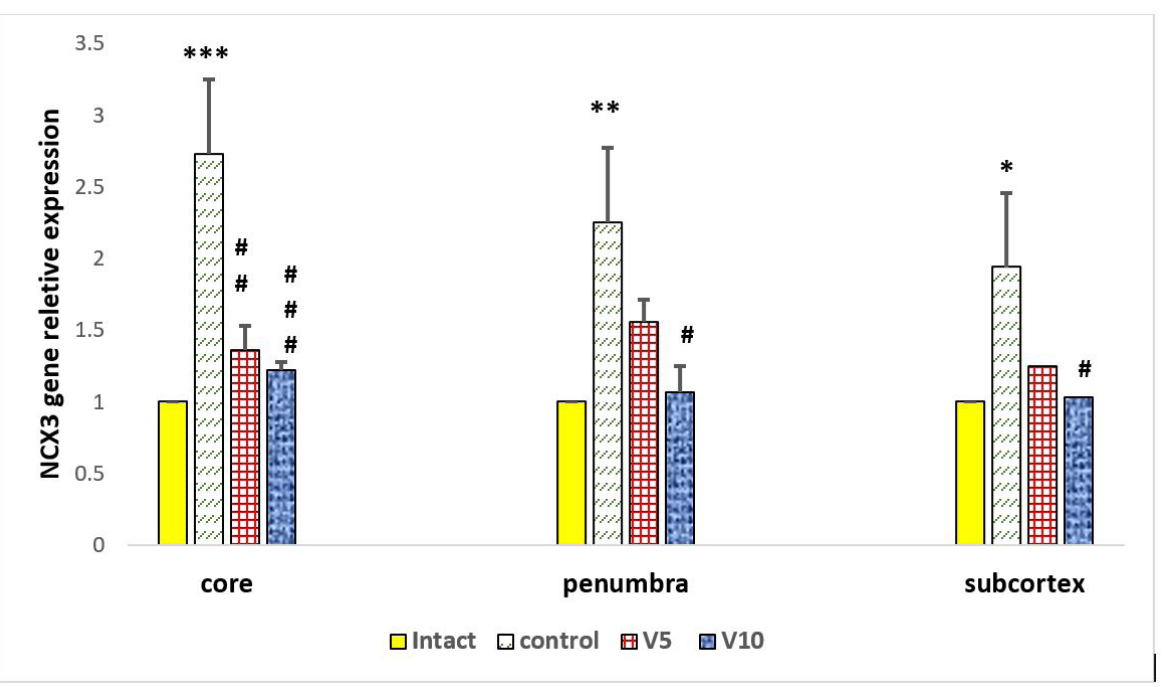

NEUR $\$ S C I E N C E$

Figure 4. Relative expression of NCX3 in the intact (Healthy Rats, $\mathrm{n}=4$ ), control (MCAO, n=4), V5 (Viola spathulata, $5 \mathrm{mg} / \mathrm{kg} / \mathrm{d}$ pretreatment with MCAO operation $(\mathrm{n}=4)$, and V10 (Viola spathulata, $10 \mathrm{mg} / \mathrm{kg} / \mathrm{d}$; pretreatment with MCAO operation $(\mathrm{n}=4)$ groups detected by Real-Time Polymerase Chain Reaction (RT-PCR)

NCX3 transcript was upregulated in the control group compared with the intact groups. NCX3 transcript was down-regulated in the V5 and V10 groups compared with the control group.

Values are presented as Means \pm SEM obtained from two independent experiments in the core, penumbra and subcortex areas of the brain. ${ }^{*} \mathrm{P}<0.05,{ }^{* *} \mathrm{P}<0.01,{ }^{* * *} \mathrm{P}<0.001$ compared with the intact group.

$\# \mathrm{P}<0.05, \# \# \mathrm{P}<0.01$, and \#\#\#P<0.001 compared with the control group. 


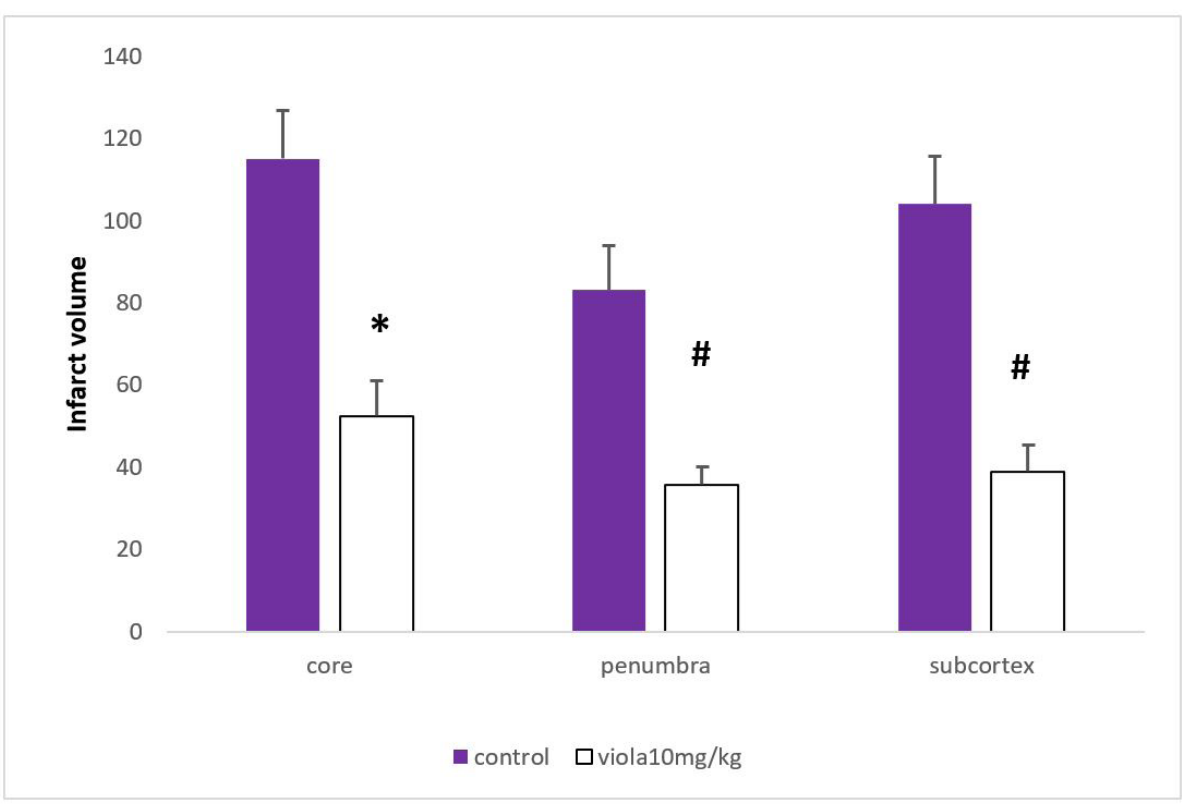

NEUR:SCIENCE

Figure 3. The effect of Viola spathulata $(10 \mathrm{mg} / \mathrm{kg})$ pretreatment on infarct volume in the core, penumbra and subcortex areas compared with the control group $(\mathrm{n}=7)$.

Values are presented as Mean \pm SEM obtained From two independent experiments in the core, penumbra and subcortex of the brain.

${ }^{*} \mathrm{P}<0.05, \# \mathrm{P}<0.001$.

impairment induced by MCA occlusion. Our findings showed that pretreatment with $V$. spathulata downregulated $N C X 3$ transcription in the brain of MCAO rats. NCX activity causes calcium entry, which leads to lethal calcium load, and the inhibition of NCX may be protective in excitotoxicity when ATP depletion occurs (Czyż \& Kiedrowski, 2002; Jeffs, Meloni, Bakker, \& Knuckey, 2007). The mechanism by which $V$. spathulata pretreatment reduced ischemic damage could be partly due to downregulating $N C X 3$ gene transcription and protecting the cells from lethal calcium load in ischemia conditions. However, the $N C X 3$ protein level was not evaluated by the western blot technique in our study, which is recommended to be addressed in further studies.

\section{Conclusion}

Regarding the effects of $V$. spathulata pretreatment on IV, NDS, and $N C X 3$ gene transcription, our data suggested that $V$. spathulata extract has a neuroprotective role. $V$. spathulata extract reversed the deleterious effects of ischemia-reperfusion on cells, possibly by overcoming the $\mathrm{Ca}^{2+}$ overload through regulating $N C X 3$ gene transcription. Further studies are required to extend or confirm these observations. Ultimately, it is hoped that novel cerebroprotective strategies be developed for those at risk of stroke or for cases whose cerebral perfusion is electively reduced at the time of surgery.

\section{Ethical Considerations}

Compliance with ethical guidelines

All experimental animal procedures were approved and conducted under the Animal Research and Ethics Committee (IR.GUMS.REC.1394.323) of Guilan University of Medical Sciences.

\section{Funding}

The present study was funded by grants from the Research Deputy of Guilan University of Medical Sciences (Rasht, Iran).

\section{Authors' contributions}

All authors equally contributed to preparing this article.

\section{Conflict of interest}

The authors declared no conflict of interest.

\section{Acknowledgments}

This work was financially supported by research deputy of Guilan University of Medical Sciences. 


\section{References}

Amantea, D., Marrone, M. C., Nistico, R., Federici, M., Bagetta, G., Bernardi, G., et al. (2009). Oxidative stress in stroke pathophysiology: Validation of hydrogen peroxide metabolism as a pharmacological target to afford neuroprotection. International Review of Neurobiology, 85, 363-74. [DOI:10.1016/ S0074-7742(09)85025-3] [PMID]

Ansari, M., Rafiee, K., Yasa, N., Vardasbi, S., Naimi, S., \& Nowrouzi, A. (2010). Measurement of melatonin in alcoholic and hot water extracts of Tanacetum parthenium, Tripleurospermum disciforme and Viola odorata. DARU Journal of Pharmaceutical Sciences, 18(3), 173-8. [PMID] [PMCID]

Bacigaluppi, M., Pluchino, S., Martino, G., Kilic, E., \& Hermann D. M. (2008). Neural stem/ precursor cells for the treatment of ischemic stroke. Journal of the Neurological Sciences, 265(12), 73-7. [DOI:10.1016/j.jns.2007.06.012] [PMID]

Bano, D., Young, K. W., Guerin, C. J., LeFeuvre, R., Rothwell, N. J., Naldini, L., et al. (2005). Cleavage of the plasma membrane $\mathrm{Na}^{+} / \mathrm{Ca}^{2+}$ exchanger in excitotoxicity. Cell, 120(2), 275-85. [DOI:10.1016/j.cell.2004.11.049] [PMID]

Blaustein, M. P., \& Lederer, W. J. (1999). Sodium/calcium exchange: Its physiological implications. Physiological Reviews, 79(3), 763-854. [DOI:10.1152/physrev.1999.79.3.763] [PMID]

Bora, K. S., Arora, S., \& Shri, R. (2011). Role of Ocimum basilicum L. in prevention of ischemia and reperfusion-induced cerebral damage, and motor dysfunctions in mice brain. Journal of Ethnopharmacology, 137(3), 1360-5. [DOI:10.1016/j. jep.2011.07.066] [PMID]

Boscia, F., Gala, R., Pignataro, G., De Bartolomeis, A., Cicale, M., Ambesi-Impiombato, A., et al. (2006). Permanent focal brain ischemia induces isoform-dependent changes in the pattern of $\mathrm{Na}^{+} / \mathrm{Ca}^{2+}$ exchanger gene expression in the ischemic core, periinfarct area, and intact brain regions. Journal of Cerebral Blood Flow \& Metabolism, 26(4), 502-17. [DOI:10.1038/ sj.jcbfm.9600207] [PMID]

Canitano, A., Papa, M., Boscia, F., Castaldo, P., Sellitti, S., Taglialatela, M., et al. (2002). Brain distribution of the $\mathrm{Na}^{+} / \mathrm{Ca}^{2+}$ exchanger-encoding genes NCX1, NCX2, and NCX3 and their related proteins in the central nervous system. Annals of the New York Academy of Sciences, 976(1), 394-404 [DOI:10.1111/j.1749-6632.2002.tb04766.x] [PMID]

Chen, G., Huo, Y., Tan, D. X., Liang, Z., Zhang, W., \& Zhang, Y (2003). Melatonin in Chinese medicinal herbs. Life Sciences, 73(1), 19-26. [DOI:10.1016/S0024-3205(03)00252-2]

Czyż, A., \& Kiedrowski, L. (2002). In depolarized and glucosedeprived neurons, $\mathrm{Na}^{+}$influx reverses plasmalemmal $\mathrm{K}^{+}$-dependent and $\mathrm{K}^{+}$-independent $\mathrm{Na}^{+} / \mathrm{Ca}^{2+}$ exchangers and contributes to NMDA excitotoxicity. Journal of Neurochemistry, 83(6), 1321-8. [DOI:10.1046/j.1471-4159.2002.01227.x] [PMID]

Dirnagl, U., Iadecola, C., \& Moskowitz, M. A. (1999). Pathobiology of ischaemic stroke: An integrated view. Trends in Neurosciences, 22(9), 391-7. [DOI:10.1016/S0166-2236(99)01401-0]

Jeffs, G. J., Meloni, B. P., Bakker, A. J., \& Knuckey, N. W. (2007) The role of the $\mathrm{Na}^{+} / \mathrm{Ca}^{2+}$ exchanger (NCX) in neurons following ischaemia. Journal of Clinical Neuroscience, 14(6), 507-14. [DOI:10.1016/j.jocn.2006.07.013] [PMID]

Kim, Y. J., Yoon, Y. H., \& Park, W. J. (2011). Supply of tryptophan and tryptamine influenced the formation of melatonin in Vio- la plants. Journal of Life Science, 21(2), 328-33. [DOI:10.5352/ JLS.2011.21.2.328]

Koochek, M., Pipelzadeh, M., \& Mardani, H. (2003). The effectiveness of Viola odorata in the prevention and treatment of formalin-induced lung damage in the rat. Journal of Herbs, Spices \& Medicinal Plants, 10(2), 95-103. [DOI:10.1300/ J044v10n02_11]

Lei, B., Popp, S., Capuano-Waters, C., Cottrell, J., \& Kass, I. (2004). Lidocaine attenuates apoptosis in the ischemic penumbra and reduces infarct size after transient focal cerebral ischemia in rats. Neuroscience, 125(3), 691-701. [DOI:10.1016/j.neuroscience.2004.02.034] [PMID]

Letechipía-Vallejo, G., González-Burgos, I., \& Cervantes, M (2001). Neuroprotective effect of melatonin on brain damage induced by acute global cerebral ischemia in cats. Archives of Medical Research, 32(3), 186-92. [DOI:10.1016/S01884409(01)00268-5]

Lin, C., Chao, H., Li, Z., Xu, X., Liu, Y., Hou, L., et al. (2016). Melatonin attenuates traumatic brain injury-induced inflammation: a possible role for mitophagy. Journal of Pineal Research, 61(2), 177-86. [DOI:10.1111/jpi.12337] [PMID]

Lipton, P. (1999). Ischemic cell death in brain neurons. Physiological Reviews, 79(4), 1431-568. [DOI:10.1152/physrev.1999.79.4.1431] [PMID]

Liu, L. F., Qin, Q., Qian, Z. H., Shi, M., Deng, Q. C., Zhu, W. P., et al. (2014). Protective effects of melatonin on ischemiareperfusion induced myocardial damage and hemodynamic recovery in rats. European Review for Medical and Pharmacological Sciences, 18(23), 3681-6. [PMID]

Livak, K. J., \& Schmittgen, T. D. (2001). Analysis of relative gene expression data using real-time quantitative PCR and the 2(-Delta Delta C(T)) Method. Methods, 25(4), 402-8. [DOI:10.1006/meth.2001.1262] [PMID]

Longa, E. Z., Weinstein, P. R., Carlson, S., \& Cummins, R. (1989). Reversible middle cerebral artery occlusion without craniectomy in rats. Stroke, 20(1), 84-91. [DOI:10.1161/01. STR.20.1.84] [PMID]

Manchester, L. C., Coto-Montes, A., Boga, J. A., Andersen, L. P. H., Zhou, Z., Galano, A., et al. (2015). Melatonin: An ancien molecule that makes oxygen metabolically tolerable. Journal of Pineal Research, 59(4), 403-19. [DOI:10.1111/jpi.12267] [PMID]

Manzanero, S., Santro, T., \& Arumugam, T. V. (2013). Neurona oxidative stress in acute ischemic stroke: Sources and contribution to cell injury. Neurochemistry International, 62(5), 712 8. [DOI:10.1016/j.neuint.2012.11.009] [PMID]

Mao, L., Dauchy, R. T., Blask, D. E., Dauchy, E. M., Slakey, L. M., Brimer, S., et al. (2016). Melatonin suppression of aerobic glycolysis (Warburg effect), survival signalling and metastasis in human leiomyosarcoma. Journal of Pineal Research, 60(2), 167-77. [DOI:10.1111/jpi.12298] [PMID]

Mergenthaler, P., Dirnagl, U., \& Meisel, A. (2004). Pathophysiology of stroke: Lessons from animal models Metabolic Brain Disease, 19(3-4), 151-67. [DOI:10.1023/ B:MEBR.0000043966.46964.e6] [PMID]

Meyer, F. B. (1989). Calcium, neuronal hyperexcitability and ischemic injury. Brain Research Reviews, 14(3), 227-43. [DOI:10.1016/0165-0173(89)90002-7] 
Mohagheghi, F., Bigdeli, M. R., Rasoulian, B., Zeinanloo, A. A., \& Khoshbaten, A. (2010). Dietary virgin olive oil reduces blood brain barrier permeability, brain edema, and brain injury in rats subjected to ischemia-reperfusion. The Scientific World Journal, 10, 1180-191. [DOI:10.1100/tsw.2010.128] [PMID] [PMCID]

Mohammadi, E., \& Bigdeli, M. R. (2014). Time course of neuroprotection induced by normobaric hyperoxia and NCX1 expression. Brain Injury, 28(8), 1127-34. [DOI:10.3109/02699 052.2014.896472] [PMID]

Mousavi, S. H., Naghizade, B., Pourgonabadi, S., \& Ghorbani, A. (2016). Protective effect of Viola tricolor and Viola odorata extracts on serum/glucose deprivation-induced neurotoxicity: Role of reactive oxygen species. Avicenna Journal of Phytomedicine, 6(4), 434-41. [PMID] [PMCID]

Murch, S. J., Simmons, C. B., \& Saxena, P. K. (1997). Melatonin in feverfew and other medicinal plants. The Lancet, 350(9091), 1598-9. [DOI:10.1016/S0140-6736(05)64014-7] [PMID]

Nduhirabandi, F., Lamont, K., Albertyn, Z., Opie, L. H., \& Lecour, S. (2016). Role of toll-like receptor 4 in melatonininduced cardioprotection. Journal of Pineal Research, 60(1) 39-47. [DOI:10.1111/jpi.12286] [PMID]

Papa, M., Canitano, A., Boscia, F., Castaldo, P., Sellitti, S., Porzig, H., et al. (2003). Differential expression of the $\mathrm{Na}+-\mathrm{Ca}^{2+}$ exchanger transcripts and proteins in rat brain regions. Journal of Comparative Neurology, 461(1), 31-48. [DOI:10.1002/ cne.10665] [PMID]

Pignataro, G., Gala, R., Cuomo, O., Tortiglione, A., Giaccio, L., Castaldo, P., et al. (2004). Two sodium/calcium exchanger gene products, NCX1 and NCX3, play a major role in the development of permanent focal cerebral ischemia. Stroke, 35(11) 2566-70. [DOI:10.1161/01.STR.0000143730.29964.93] [PMID]

Robertson, N. J., Faulkner, S., Fleiss, B., Bainbridge, A., Andorka, C., Price, D., et al. (2012). Melatonin augments hypothermic neuroprotection in a perinatal asphyxia model. Brain, 136(1), 90-105. [DOI:10.1093/brain/aws285] [PMID]

Secondo, A., Staiano, R. I., Scorziello, A., Sirabella, R., Boscia, F., Adornetto, A., et al. (2007). BHK cells transfected with NCX3 are more resistant to hypoxia followed by reoxygenation than those transfected with NCX1 and NCX2: Possible relationship with mitochondrial membrane potential. Cell Calcium, 42(6) 521-35. [DOI:10.1016/j.ceca.2007.01.006] [PMID]

Swanson, R. A., Morton, M. T., Tsao-Wu, G., Savalos, R. A., Davidson, C., \& Sharp, F. R. (1990). A semiautomated method for measuring braininfarct volume. Journal of Cerebral Blood Flow \& Metabolism, 10(2), 290-3. [DOI:10.1038/jcbfm.1990.47] [PMID]

Vekaria, R. H., Patel, M. N., Bhalodiya, P. N., Patel, V., Desai, T. R., \& Tirgar, P. R. (2012). Evaluation of neuroprotective effect of Coriandrum sativum linn. against ischemicreperfusion insult in brain. International Journal of Phytopharmacology, 3(2), 186-93. file:///C:/Users/Z.Ganipour/Downloads/17. rutvi\%20(2).pdf

Yanpallewar, S., Rai, S., Kumar, M., \& Acharya, S. (2004). Evaluation of antioxidant and neuroprotective effect of Ocimum sanctum on transient cerebral ischemia and long-term cerebral hypoperfusion. Pharmacology Biochemistry and Behavior, 79(1), 155-64. [DOI:10.1016/j.pbb.2004.07.008] [PMID]

Yeung, H., Hung, M., \& Fung, M. (2008). Melatonin ameliorates calcium homeostasis in myocardial and ischemia-reperfusion injury in chronically hypoxic rats. Journal of Pineal Research 45(4), 373-82. [DOI:10.1111/j.1600-079X.2008.00601.x] [PMID] 